\title{
Seed production of 'Grasslands Roa' tall fescue in Southland
}

\author{
M.J. HICKEY* \\ DSIR Grasslands, Private Bag, Gore
}

\begin{abstract}
Roa tall fescue was sown at Gore to study the effects of viable seeding rate $(2.5,5.0$ and 10.0 $\mathrm{kg} / \mathrm{ha})$ and row spacing $(30$ and $60 \mathrm{~cm})$ on seed yield and seed quality over 3 harvest seasons. In the first year after mid-February sowing, seed yields were low (260 kg/ha), owing to slow establishment and weed competition. The $30-\mathrm{cm}$ row spacing had the highest seed yield in this year, but there were no differences between viable seeding rates. In the second year the highest seed yields $(800 \mathrm{~kg} / \mathrm{ha})$ were from the viable 2.5 and $5.0 \mathrm{~kg} / \mathrm{ha}$ seeding rates, but there were no differences between row spacings. In the third year there were no differences in seed yield between viable seeding rates and row spacing. The cool, moist summer conditions had no adverse effect on seed development; seed weights (3.3 g/1000 seeds) were high for all treatments each year.
\end{abstract}

Keywords-'Grasslands-Roa' tall fescue, seed yields, seed quality, seed rates, row spacings, lodging

\section{Introduction}

'Grasslands Roa' tall fescue (Festuca arundinacea Schreb.) has been successfully grown for seed production in the Manawatu, yielding up to $800 \mathrm{~kg}$ of seed/ha at low seeding rates $(3.0 \mathrm{~kg} / \mathrm{ha})$ and $60-\mathrm{cm}$ row spacing (Brown et al. 1988). Tall fescue requires a moisture-retentive soil for good establishment and seed production (Brock 1983). The Southland region of New Zealand appears suitable for seed production, provided its moist summer climate does not cause plant disease problems such as blind seed (Gleotina temulenta Prill \& Delacr) and ergot (Claviceps purpurea Fr.).

A trial was established to examine the seed yield and seed quality of Roa tall fescue in Southland.

\section{Materials and methods}

The experiment was sited at the DSIR Grasslands Regional station at Gore (latitude 46" south) on a

*Now at DSIR Grasslands, Private Bag, Palmerston North.
B-gleyed yellow-grey earth. The climate is typified by cool winters (mean $5^{\circ} \mathrm{C}$ ), and cool-warm summers (mean $14.5^{\circ} \mathrm{C}$ ). The mean annual rainfall over the trial period was $960 \mathrm{~mm}$. Monthly rainfall readings for spring/summer are presented in Table 1 .

Roa was sown in a factorial design of 3 replications. The main plots were Roa sown at 3 seeding rates of $2.5,5.0$ and $10 \mathrm{~kg} / \mathrm{ha}$ of viable seed. The subplots were row spacings of 30 and $60 \mathrm{~cm}$. Each subplot consisted of 8 rows measuring $48 \mathrm{~m}$ in length. Roa was sown on 16 February 1984 at a drilled depth of $2 \mathrm{~cm}$ using an Aitcheson Seedamatic 1000. Previous summer fallow and applications of Gramoxone (3 1/ha) and dicamba 20 (1 l/ha) ensured a weed free seed bed. After establishment, $150 \mathrm{~kg} / \mathrm{ha}$ superphosphate (0-9-0-1 1) was applied in late March. Annual dressings of nitrogen as urea were applied to all treatments at stem elongation in October at a rate of $50 \mathrm{~kg} \mathrm{~N} / \mathrm{ha}$, The crop was closed in late May after grazing by sheep except for the first year when no grazings occurred.

Table 1 Monthly rainfall_(mm) September to January;

\begin{tabular}{lcccc}
\hline & mean & Year 1 & Year 2 & Year 3 \\
Month & $1951-80$ & $1984-85$ & $1985-86$ & $1986-87$ \\
\hline September & $\mathbf{6 3}$ & $\mathbf{7 7}$ & $\mathbf{4 9}$ & $\mathbf{2 1}$ \\
October & 78 & $\mathbf{7 6}$ & $\mathbf{6 1}$ & $\mathbf{6 6}$ \\
November & $\mathbf{7 6}$ & $\mathbf{7 1}$ & $\mathbf{6 4}$ & $\mathbf{1 1 2}$ \\
December & $\mathbf{8 3}$ & $\mathbf{9 7}$ & $\mathbf{7 6}$ & $\mathbf{8 1}$ \\
January & 100 & 119 & $\mathbf{7 5}$ & $\mathbf{7 5}$ \\
\hline
\end{tabular}

Broadleaf weeds and other grasses were controlled each winter by using Tramat (10 1/ha) in the first year and $1.5 \mathrm{~kg}$ ai/ha of atrazine in the following years. Glyphosate was used in spot applications for the control of volunteer ryegrass plants.

During the period of seed head emergence and anthesis the number of reproductive tillers $/ \mathrm{m}^{2}$ were counted in four $0.5 \mathrm{~m}^{2}$ random sites per plot. Seed yields, adjusted to $14 \%$ moisture, were measured by direct heading the whole plot with a harvester during late January when the seed moisture content had declined to $35-40 \%$ and before excessive seed shedding occurred. Seed was cool-air dried and then machine dressed.

Seed purity and germination of dressed seed samples were tested by the New Zealand Seed Testing Station in Palmerston North. Thousand-seed weight was determined for each treatment using a sample of dressed seed. 
The crop residue was baled and then the stubble and regrowth grazed by sheep during the autumn.

\section{Results and discussion}

Seed yields

Tall fescue is slow to establish, particularly at low temperatures (Hill et al. 1985) that occur in autumn sowings in Southland. Mean autumn $10 \mathrm{~cm}$ soil temperatures after sowing were: March $13.2^{\circ} \mathrm{C}$, April $9.8^{\circ} \mathrm{C}$ and May $5.4^{\circ} \mathrm{C}$, recorded at the adjacent Gore climatological station. This resulted in fewer reproductive tillers $/ \mathrm{m}^{*}$ being vernalised during the first winter (Bean 1978) compared with following years (Table 2). The large weed component also caused a high percentage of seed impurities (Table 4).

Rolston \& Hare (1986) also found a substantial reduction in first year seed yields from slow establishing grass seed crops where weed competition was a problem. Atrazine was more effective in weed control in the second and third years.

Seed yields were consistently 170-180 kg/ha higher at the $30-\mathrm{cm}$ row spacing than the $60-\mathrm{cm}$ in the first 2 years. In the third year, the $30-\mathrm{cm}$ spacing also yielded $110 \mathrm{~kg} / \mathrm{ha}$ more seed than the $60-\mathrm{cm}$ spacing (Table 3).

Table 2 Number of reproductive tillers/m' for row spacing $(\mathrm{cm})$ and viable seeding rate $(\mathrm{kg} / \mathrm{ha})$.

\begin{tabular}{|c|c|c|c|c|c|}
\hline \multirow[b]{2}{*}{ Harvests } & \multirow[b]{2}{*}{ Year } & \multicolumn{2}{|c|}{$\begin{array}{l}\text { Row } \\
\text { spacing } \\
\text { (cm) }\end{array}$} & \multirow{2}{*}{$\begin{array}{l}\text { lsd } \\
5 \% \\
\end{array}$} & \multirow{2}{*}{$\begin{array}{l}\text { Viable seeding Isd } \\
\text { rate } \\
\text { (kg/ha) } \\
\text { 2. } 55.010 .05 \% \\
\end{array}$} \\
\hline & & 30 & 60 & & \\
\hline | & 200 & 260 & 130 & 130 & $\begin{array}{llll}190 & 220 & 220 & 30\end{array}$ \\
\hline 2 & 260 & 270 & 240 & 30 & $\begin{array}{lllll}380 & 330 & 240 & 30\end{array}$ \\
\hline 3 & 260 & 270 & 250 & ns & $\begin{array}{llll}350 & 300 & 240 & 40\end{array}$ \\
\hline Lsd $5 \%$ & 20 & & & & \\
\hline
\end{tabular}

Table 3 Effect of row spacing and viable seeding rate on seed yield $(\mathrm{kg} / \mathrm{ha})$ at $14 \%$ seed moisture.

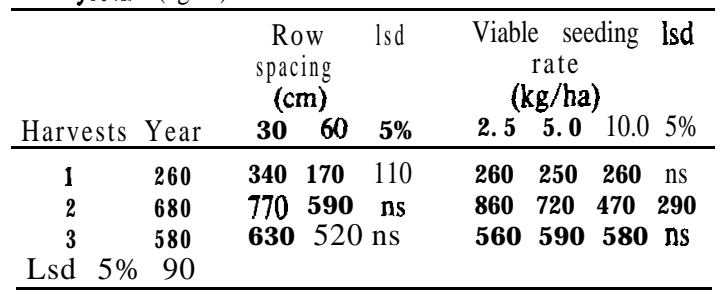

Seeding rate had no effect on seed yield in the first year (Table 3), probably because of an increase in spikelet and/or floret numbers to compensate for the lower number of reproductive tillers at the lowest seeding rate (Hare et $\boldsymbol{a l}$. 1988). The lower seeding rates had higher yields in the second and third years owing to more reproductive tillers $/ \mathrm{m}^{2}$. These tillers were probably heavier and produced more seeds/tiller than tillers at higher rates (Hare et al. 1988). The tillers at the higher seeding rates must have suffered from too much competition; they did not have enough space to express themselves and therefore fewer reproductive tillers developed.

The number of reproductive tillers per $\mathrm{m}^{2}$ at anthesis in the third year suggested that yields similar to those of the second year could be expected (Table 2). However, after anthesis in the third year the crop lodged in late December 1986, causing difficulty in harvesting and seed losses. These losses appeared to be heavier at the lower seeding rates (Table 3). The above average rainfall in November (Table 1) and the subsequent flush of growth caused the lodging.

\section{Seed quality}

Seed weights were in the range 3.1 to $3.4 \mathrm{~g} / 1000$ seeds regardless of seeding rates or row spacing, which is well above the average of $2.43 \mathrm{~g}$ reported by Brown et al. 1988

Roa seed purity was low in the first year (Table 4) and failed to reach certification standards for 1st generation seed (MAF 1985), because of weed contaminants that included goose grass (Bromus mollis L.), meadow grass (Poa trivialis L.), dandelion (Taraxacum officinale $\mathrm{L}$.) and hawkweed (Crepis capillaris L.). Seed quality in the second and third years reached 1st generation certification standard (MAF 1987).

Germination of machine-dressed seed over a period of 14 days (Table 4) was highest in the first year and declined by $5 \%$ in the third year. Ergot was found in some of the seed samples and could have reduced seed germinability, though its effect on seed purity was minor $((0.2 \%)$. Though blind seed affects germination in both ryegrass and tall fescue seed crops in wet, cool summers (Latch 1980), it was not observed in this experiment.

Table 4 Mean yearly percentage seed impurities and germination after 14 days of machined dressed seed (analysis on arcsin values).

\begin{tabular}{|c|c|c|}
\hline Harvest years & Impurities & Germination \\
\hline 1 & 2.8 & 88 \\
\hline 2 & 0.3 & 86 \\
\hline 3 & 1.1 & 83 \\
\hline Lsd $5 \%$ & 0.4 & 0.3 \\
\hline
\end{tabular}

\section{Conclusions}

1. Autumn-sown Roa seed crops produce a very light crop in the first year of establishment.

2. Efficient weed control is essential in the first year for control of fast establishing weed species.

3. Sowing rate should be 2.5 or $5 \mathrm{~kg} / \mathrm{ha}$ of viable seed, and row spacing $30 \mathrm{~cm}$.

4. Seed yield and quality can be good in the Southland climate. However, wet summers can cause lodging.

5. Research is needed into the effects of plant diseases such as blind seed in Southland seed crops. 


\section{ACKNOWLEDGEMENTS}

The assistance given by DSIR Crop Research staff Gore in harvesting and use of drying equipment and also staff at the New Zealand Seed Testing Station Palmerston North for seed purity and germination analysis. Mr Ken Moore DSIR Grasslands, Palmerston North for seed cleaning. Thanks also to Mr K.H. Widdup, DSIR Grasslands, Gore, for advice and comment.

\section{REFERENCES}

Bean, E.W. 1978, Principles of herbage seed production 2nd Ed. Welsh Plant Breeding Station.

Brock, J.L. 1983. 'Grasslands Roa' tall fescue: A review. Proceedings of the NZ Grassland Association 44: $74-80$.

Brown, K.R.; Rolston, M.P.; Hare, M.D.; Archie, W.J. 1988. Time of closing for 'Grasslands Roa' tall fescue seed crops. NZ journal of agricultural research 3I: 383-388.

Hare, M.D.; Rolston, M.P.; Falloon, R.E.; Hickson, R.E 1988. Autumn sowing date and seeding rate affect seed production of prairie grass. Journal of applied seed production 6: 46-54.

Hill, M.J.; Pearson, C.J.; Kirby, A.C. 1985. Germination and seedling growth of prairie grass, tall fescue and Italian ryegrass at different temperatures. Australian journal agricultural research 36: 13-24.

Latch, G.C. 1980. Importance of disease in herbage seed production. In Herbage Seed Production J.A Lancashire (ed.). Grasslands Research and Practice Series I: 36-40.

Rolston, M.P.; Hare, M.D. 1986. Competitive effects of weed on seed yield of first year grass seed crops. Journal of applied seed production 4: 34-36. 